\title{
DISTRIBUSI SPASIAL IKAN BARONANG Siganus canaliculatus Park, 1797 PADA HABITAT PADANG LAMUN BERBEDA DI TELUK AMBON DALAM
}

\author{
SPATIAL DISTRIBUTION OF WHITE-SPOTTED RABBIT FISH \\ Siganus canaliculatus Parak, 1797 ON DIFFERENT SEAGRASS \\ BEDS HABITAT OF THE INNER AMBON BAY
}

\author{
Husain Latuconsina ${ }^{1,2 *}$, Ridwan Affandi ${ }^{3}$, M. Mukhlis Kamal ${ }^{3}$, \& Nurlisa A. Butet ${ }^{3}$ \\ ${ }^{1}$ Departemen Biologi, FMIPA-UNISMA, Malang, 65144, Indonesia \\ ${ }^{2}$ Program Doktor Pengelolaan Sumberdaya Perairan, IPB, Bogor, 16680, Indonesia \\ ${ }^{3}$ Departemen Manajemen Sumberdaya Perairan, FPIK-IPB, Bogor, 16680, Indonesia \\ *E-mail: husainlatuconsina@ymail.com
}

\begin{abstract}
White-spotted rabbit fish Siganus canaliculatus is a type of demersal fish that is associated with the seagrass beds, both as a nursery ground, feeding ground and for protection from predators. The purpose of this study was to analyze the spatial distribution of S. canaliculatus in different seagrass beds. The research was conducted from August 2018 until July 2019 in the inner Ambon Bay. Fish samples were collected using beach seines. The measurement of the environmental parameters, was done as well at the same time. Statistic analysis showed in table, histogram, dendrogram, and biplot graphic. The results showed that as many as 1.050 white-spotted rabbit fish individual consisting of 598 males and 452 females, were found during the study. The environmental parameters are generally still supporting the life of $S$. canaliculatus had different preferences habitat based on its life cycle. The adults size tend to be distributed in monospecific seagrass beds. On the contrary this result was inversely to the adult size that associated to mixed seagrass beds, and juvenile size, which was widely distributed on various habitats type that proves seagrass beds function as a nursery ground.
\end{abstract}

Keywords: Ambon Bay, seagrass beds, Siganus canaliculatus, spatial distribution

\begin{abstract}
ABSTRAK
Ikan baronang Siganus canaliculatus merupakan jenis ikan demersal yang berasosiasi dengan padang lamun sebagai tempat asuhan dan pembesaran, mencari makan dan perlindungan. Penelitian ini bertujuan untuk menganalisis distribusi spasial $S$. canaliculatus pada habitat padang lamun berbeda. Penelitian dilaksanakan pada Agustus 2018-Juli 2019 di perairan Teluk Ambon Dalam. Ikan dikoleksi menggunakan pukat pantai bersamaan dengan pengukuran parameter lingkungan. Analisis statistik ditampilkan secara deskriptif dalam bentuk tabel, histogram, dendrogram dan grafik biplot. Hasil penelitian mendapatkan sebanyak 1.050 ekor yang terdiri atas 598 jantan dan 452 betina. Parameter lingkungan secara umum medukung kehidupan $S$. canalicultus yang memiliki preferensi habitat berbeda berdasarkan stadia hidupnya, kelompok ukuran dewasa cenderung terdistribusi pada habitat lamun vegetasi tunggal, berbanding terbalik dengan ukuran pradewasa pada habitat padang lamun vegetasi campuran, sedangkan ukuran juvenil terdistribusi luas pada berbagai tipe habitat yang membuktikan fungsi padang lamun sebagai tempat asuhan dan pembesaran.
\end{abstract}

Kata kunci: distribusi spasial, padang lamun, Siganus canaliculatus, Teluk Ambon

\section{PENDAHULUAN}

Lamun adalah tumbuhan berbunga yang hidup pada perairan pasang surut, berperan sebagai pelindung dan penstabil garis pantai (Christianen et al., 2013; Ondiviela et al., 2014), produsen primer (Erftemeijer et al., 1993), pensiklus nutrien (Erftemeijer \& Middelburg, 1995), tempat proses biogeokimia (Thangaradjou et al., 
2015), habitat makrofauna bentik (Junhui et al., 2018), habitat ikan (Erftemeijer \& Allen, 1993; Ambo-Rappe et al., 2013; Phinrub et al., 2015 ), pembesaran ikan juvenil (Jones, 2014; McDevitt-Irwin et al., 2016; Jianguo et al., 2018), sumber makanan ikan juvenil (Nakamura et al., 2012; Kwak et al., 2015); sumber makanan langsung hewan herbivora (Scott et al., 2018); penghubung distribusi spasial ikan antar habitat (habitat ontogenetik) pada perairan pesisir (Campbell et al., 2011; Whitfield, 2017; Lee et al., 2019); pendukung stok perikanan (Unsworth et al., 2010), ketahanan pangan (Unsworth et al., 2014), sumber mata pencaharian nelayan (Syukur et al., 2017), dan mendukung kegiatan perikanan (subsisten, komersial dan rekreasi) global (De la Torre-Castro et al., 2014; Nordlund et al., 2018; Jeyabaskaran et al., 2018; Unsworth et al., 2019). Habitat padang lamun umumnya pada perairan pantai, estuari, daerah intertidal, subtidal sampai terumbu karang dengan beragam tipe substrat (Waycott et al., 2004).

Perairan Teluk Ambon Dalam (TAD) dicirikan oleh hamparan padang lamun yang tersebar pada beberapa kawasan dengan karakteristik lingkungan yang berbeda membentuk vegetasi tunggal maupun campuran, yang berada dekat muara sungai maupun yang jauh dari muara sungai (Irawan \& Nganro, 2016). Keberadaan habitat padang lamun di perairan TAD mendukung biodiversitas dan kelimpahan ikan yang berasosiasi di dalamnya (Latuconsina et al., 2012; Latuconsina \& Ambo-Rappe, 2013; Ambo-Rappe et al., 2013).

Jenis ikan dominan yang dikenal berasosiasi kuat dengan habitat padang lamun adalah S. canaliculatus (Kuriandewa et al., 2003). Di perairan TAD, $S$. canaliculatus menunjukkan variasi kelimpahan temporal berdasarkan periode bulan (Latuconsina et al., 2012) dan periode siang dan malam (Latuconsina \& AmboRappe, 2013). Selain berasosiasi dengan padang lamun, $S$. canaliculatus juga memperlihatkan preferensi habitat yang beragam termasuk estuari-mangrove, dan terumbu karang (Latuconsina et al., 2015; Latuconsina et al., 2018; Suardi et al., 2016).

Keragaman dan kerapatan jenis lamun berhubungan erat dengan kelimpahan dan ukuran ikan baronang. Hyndes et al. (2003); McCloskey \& Unsworth (2015), Ambo-Rappe (2016); dan Susilo et al. (2018) menemukan perbedaan kelimpahan, keragaman dan ukuran ikan berdasarkan perbedaan struktur kanopi vegetasi lamun. Beberapa peneliti lainnya (Ambo-Rappe 2010; Munira et al., 2010; Latuconsina et al., 2013) menemukan hubungan positif antara keragaman dan kerapatan vegetasi lamun dengan kelimpahan S. canaliculatus. Adapun berdasarkan jenis kelamin ikan, Munira et al. (2010) menemukan bahwa $S$. canaliculatus jantan dan betina berada pada sebaran spasial yang sama, ikan baronang berukuran kecil cenderung berasosiasi dengan lamun yang morfologi daunnya berukuran besar.

Penelitian ini bertujuan untuk menganalisis distribusi spasial ikan baronang $S$. canaliculatus pada habitat padang lamun dengan karakteristik fisik yang berbeda dan kaitannya dengan parameter lingkungan perairan di TAD. Hasil penelitian diharapkan menjadi informasi penting terkait peranan ekologi padang lamun untuk mendorong upaya pengelolaannya sebagai habitat esensial dan potensial bagi ikan baronang $S$. canaliculatus sehingga dapat mendukung perikanan berkelanjutan berbasis ekosistem.

\section{METODE PENELITIAN}

\subsection{Waktu dan Lokasi Penelitian}

Penelitian dilaksanakan pada Agustus 2018-Juli 2019 di perairan TAD, Maluku (Figure 1). Stasiun pengamatan sebanyak 4 lokasi dipilih secara purposif berdasarkan kriteria padang lamun vegetasi tunggal dan campuran (Irawan \& Nganro, 2016). Keempat stasiun tersebut adalah: 1) Tanjung Tiram dan 2) Halong berupa padang lamun dengan vegetasi campuran, serta 3) Poka dan 4) Nania adalah padang lamun dengan 
vegetasi tunggal.

\subsection{Pengumpulan Data}

Kerapatan dan keragaman jenis lamun diestimasi menggunakan metode sistematik sampling dengan bantuan transek garis dan kuadran (Setyobudiandi et al., 2009), masing-masing stasiun menggunakan 5 transek dengan jarak antar transek $40 \mathrm{~m}$ dan setiap transek menggunakan 10 kuadran dengan jarak antar kuadran $10 \mathrm{~m}$. Identifikasi jenis lamun merujuk kepada Waycott et al. (2004). Sampel ikan ditangkap sekali dalam sebulan menggunakan pukat pantai (panjang $30 \mathrm{~m}$, panjang sayap masing-masing $14 \mathrm{~m}$, mesh size 0,74 inci, panjang kantong dan lebar bukaan mulut $3 \mathrm{~m}$ dengan mesh size 0,25 inci, lebar/tinggi jaring $2 \mathrm{~m}$ ) yang pengoperasiannya dengan metode penyapuan pada areal padang lamun (metode swept area) yang telah diestimasi kerapatan dan keragaman lamun pada setiap stasiun pengamatan. Sampel ikan yang terkumpul disimpan dalam cool box dan selanjutnya diukur panjang-bobotnya di laboratorium. Sampel ikan digolongkan ke dalam 3 stadia berdasarakan ukuran tengah kelas, yaitu: Juvenil (32,5-62,5 mm), pradewasa (77,5-
122,5 mm) dan dewasa (>137,5 mm), merujuk pada Lam (1974); Duray (1998); Kwak et al. (2015).

Pengukuran parameter lingkungan bersamaan waktunya dengan penangkapan ikan, CTD digunakan untuk mengukur parameter kedalaman, kekeruhan, suhu, salinitas, dan klorofil-a. Adapun nilai $\mathrm{pH}$ diukur menggunakan $\mathrm{pH}$ meter Hanna. Sampel air diambil kompositnya menggunakan botol Nansen (untuk pengukuran kondisi kimiawi perairan), volume air yang ditampung mewakili bagian tengah hingga permukaan. Selanjutnya air tersebut dipindahkan ke dalam botol BOD untuk analisis oksigen terlarut yang dilakukan dengan metode Winkler. Sebagian lainnya ditampung dalam botol polyethylene berwarna hitam untuk pengukuran ex-situ fosfat dan nitrat di Laboratorium menggunakan metode kolorimetri dengan Spektrofotometer UV-1700. Verifikasi data parameter fisika, analisis kimia air, dan pengukuran panjang ikan masing-masing dilakukan di Laboratorium Fisika, Kimia dan Biologi Oseanografi Pusat Penelitian Laut DalamLIPI Ambon.

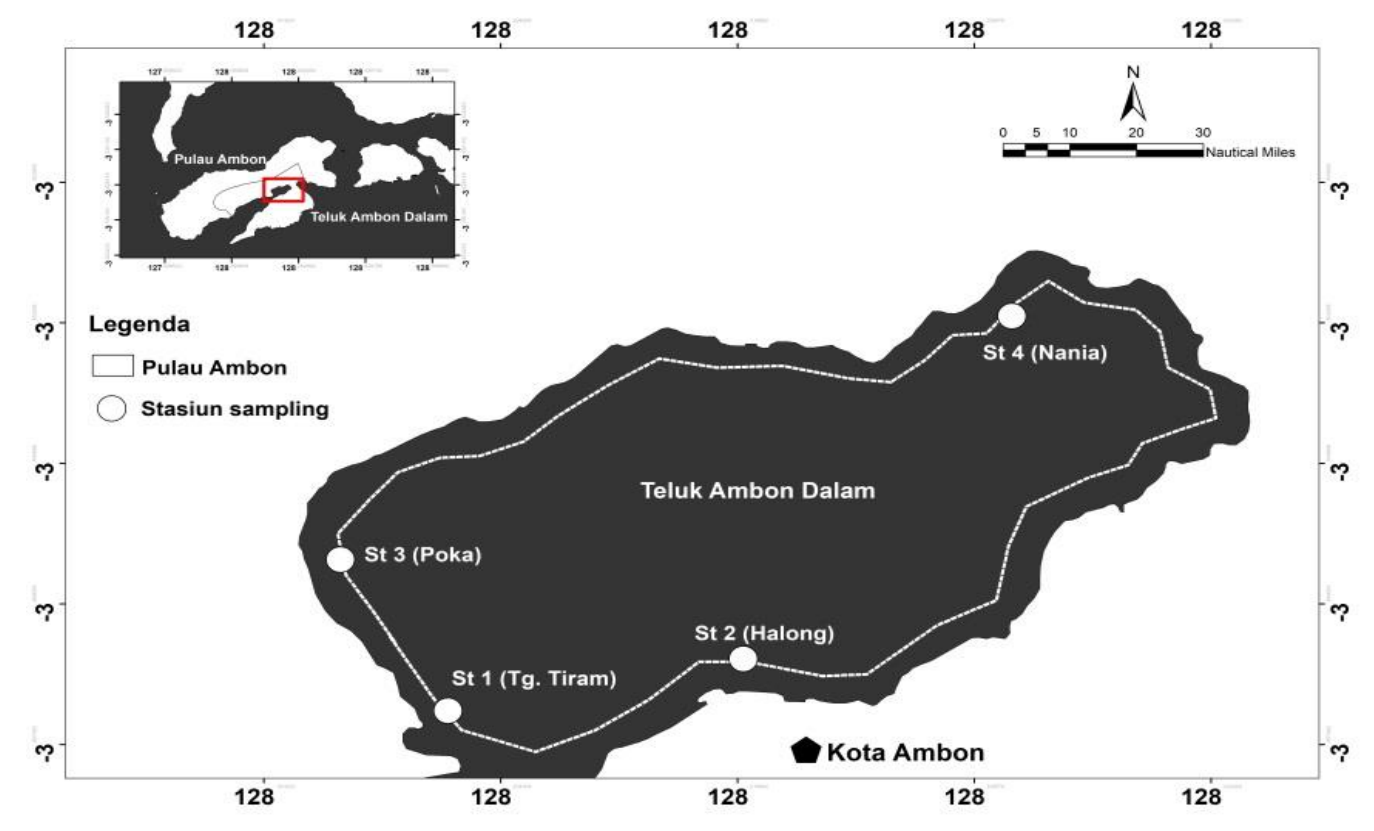

Figure 1. Map of Inner Ambon Bay with 4 research stations based on different types of seagrass beds. 


\subsection{Analisis Data}

Analisis data kerapatan lamun, kualitas air dan kelompok ukuran panjang $S$. canaliculatus dilakukan secara deskriptif yang disajikan dalam bentuk tabel dan histogram dengan bantuan program Microsoft Excel 2013. Analisis kerapatan jenis lamun sesuai petunjuk Setyobudiandi et al. (2009). Pengelompokkan struktur ukuran ikan dan korelasinya antar stasiun pengamatan dilakukan analisis komponen utama (principal component analysis, PCA) dengan pengukuran Jarak Euclidean yang ditampilkan dalam bentuk dendrogram dan biplot (Bengen, 2000; Setyobudiandi et al., 2009), selanjutnya diproses dengan menggunakan perangkat lunak Past 3.14. Jarak Euclidian $\left(\mathrm{d}^{2}\right)$ dihitung berdasarkan formula:

$\mathrm{d}^{2}\left(\mathrm{i}, \mathrm{i}^{\prime}\right)=\sum_{j=1}^{p}\left(X_{i j}-X_{i^{\prime} j}\right)^{2}$

Keterangan: $i, \vec{i}=$ stasiun pengamatan (pada baris), $\mathrm{J}=$ karakter lingkungan dan atau kelas ukuran panjang ikan pada kolom (dari 1 hingga $p$ ).

Nilai jarak Euclidean mulai dari 0 sampai tak terhingga, dimana semakin mendekati angka 0 menunjukkan kemiripan yang tinggi.

\section{HASIL DAN PEMBAHASAN}

\subsection{Kondisi Lingkungan Perairan}

Hasil pengamatan parameter fisikakimia dan biologi perairan pada habitat padang lamun pada keempat stasiun selama penelitian (Table 1).

Kedalaman perairan pada habitat padang lamun berkisar antara 0,89 $\pm 0,01$ $0,97 \pm 0,02 \mathrm{~m}$, tidak berbeda jauh antar stasiun penelitian karena topografi yang relatif sama (Table 1), yang membedakannya adalah jarak padang lamun dari garis pantai dan kedekatannya dengan muara sungai serta pemukiman. Stasiun 1 dan 2 tidak dialiri sungai namun sangat dekat $( \pm 20 \mathrm{~m})$ dengan garis pantai, dan khusus untuk stasiun 1 sangat dekat dengan pemukiman dan berhubungan langsung dengan aktivitas antropogenik, berbeda dengan stasiun 3 dan 4 yang relatif jauh $( \pm 150 \mathrm{~m})$ dari garis pantai dan dialiri sungai. Pada saat surut terendah, sebagian besar area lamun pada empat lokasi penelitian tidak tergenang air laut, sebaliknya pada saat pasang semua area lamun akan tergenang, sehingga distribusi vegetasi lamun secara alamiah turut dipengaruhi oleh tipe pasang surut di TAD yaitu campuran yang condong ke harian ganda, yaitu pergerakan air pasang naik dan surut terjadi dua kali

Table 1. The condition of the physics-chemical and biological of the waters parameters of the four research stations in the Inner Ambon Bay.

\begin{tabular}{|c|c|c|c|c|c|}
\hline \multirow{2}{*}{$\begin{array}{l}\text { Environmental } \\
\text { Parameters }\end{array}$} & \multirow[b]{2}{*}{ Unit } & \multicolumn{4}{|c|}{ Study site } \\
\hline & & $\begin{array}{l}\text { Tg. Tiram } \\
\text { (St.1) }\end{array}$ & $\begin{array}{l}\text { Halong } \\
\text { (St. 2) }\end{array}$ & $\begin{array}{c}\text { Poka } \\
\text { (St. 3) }\end{array}$ & $\begin{array}{l}\text { Nania } \\
\text { (St. 4) }\end{array}$ \\
\hline Depth & $\mathrm{m}$ & $0.92 \pm 0.01$ & $0.96 \pm 0.01$ & $0.89 \pm 0.01$ & $0.97 \pm 0.02$ \\
\hline Turbidity & NTU & $2.31 \pm 0.06$ & $1.89 \pm 0.04$ & $2.83 \pm 0.04$ & $3.49 \pm 0.10$ \\
\hline Temperature & ${ }^{\circ} \mathrm{C}$ & $28.71 \pm 0.05$ & $28.42 \pm 0.04$ & $28.71 \pm 0.05$ & $28.48 \pm 0.05$ \\
\hline Salinity & PSU & $31.38 \pm 0.03$ & $31.17 \pm 0.03$ & $30.79 \pm 0.04$ & $30.15 \pm 0.09$ \\
\hline$p H$ & & $7.47 \pm 0.01$ & $7.43 \pm 0.01$ & $7.37 \pm 0.01$ & $7.31 \pm 0.01$ \\
\hline $\begin{array}{l}\text { Dissolved } \\
\text { Oxygen }\end{array}$ & $\mathrm{mg} / \mathrm{L}$ & $6.42 \pm 0.05$ & $6.03 \pm 0.04$ & $5.96 \pm 0.04$ & $6.23 \pm 0.04$ \\
\hline $\begin{array}{l}\text { Phosphate } \\
\left(\mathrm{PO}_{4}\right)\end{array}$ & $\mathrm{mg} / \mathrm{L}$ & $0.0336 \pm 0.0006$ & $0.0347 \pm 0.0005$ & $0.0338 \pm 0.0007$ & $0.0434 \pm 0.0006$ \\
\hline Nitrate $\left(\mathrm{NO}_{3}\right)$ & $\mathrm{mg} / \mathrm{L}$ & $0.0342 \pm 0.0004$ & $0.0260 \pm 0.0003$ & $0.0266 \pm 0.0003$ & $0.0274 \pm 0.0002$ \\
\hline Chlorophyll-a & $\mathrm{mg} / \mathrm{m}^{3}$ & $1.87 \pm 0.04$ & $1.31 \pm 0.02$ & $2.00 \pm 0.04$ & $2.50 \pm 0.07$ \\
\hline
\end{tabular}


sehari dengan tinggi dan periode yang berbeda (Ondara et al., 2017). Selain itu juga dipengaruhi aktivitas antropogenik seperti sedimentasi (Irawan \& Nganro, 2016), dan ancaman perusakan fisik seperti pengerukan pasir pantai dan pencemaran limbah organik (Selano et al., 2009).

Rata-rata nilai kekeruhan $1,89 \pm 0,04$ $3,49 \pm 0,10 \mathrm{NTU}$, dengan nilai tertinggi pada stasiun 3 dan 4 yang dialiri sungai sebagai pembawa material pasir dan lumpur beserta limbah. Menurut Effendi (2003) kekeruhan disebabkan adanya bahan organik dan anorganik yang tersuspensi dan terlarut berupa lumpur dan pasir halus, maupun bahan organik dan anorganik. Kekeruhan menurut Burhanuddin (2019), juga dapat disebabkan adanya partikel koloid dan suspensi polutan berupa bahan organik dan anorganik dari buangan industri, rumah tangga, dan budidaya perikanan, yang dapat mengurangi transparansi perairan laut, sehingga memengaruhi jumlah cahaya yang tersedia untuk fotosintesis fitoplankton dan alga bentik. Bulmer et al. (2018) menemukan kandungan nutrien anorganik dan klorofil yang lebih tinggi pada habitat lamun dengan kekeruhan yang tinggi dan rendahnya produktivitas primer, sebaliknya penghilangan nutrien yang tinggi terjadi di padang lamun dengan kekeruhan rendah dengan produktivitas primer tinggi.

Kekeruhan umumnya berkorelasi negatif dengan kelimpahan komunitas ikan (Latuconsina et al., 2012; Latuconsina \& Ambo-Rappe, 2013), meskipun demikian, nilai kekeruhan yang didapatkan selama penelitian ini masih dapat ditolerir oleh $S$. canaliculatus yang ditemukan melimpah pada stasiun 3 dan 4 yang dialiri mura sungai. Fenomena ini membuktikan bahwa $S$. canaliculatus mampu hidup pada kondisi perairan dengan kekeruhan yang relatif tinggi, sebagaimana menurut Woodland (2001) bahwa $S$. canaliculatus mampu hidup pada perairan yang keruh seperti muara sungai dan sekitarnya terutama pada habitat padang lamun.
Nilai rata-rata suhu adalah $28,42 \pm 0,04-28,71 \pm 0,05^{\circ} \mathrm{C}$. S. canaliculatus hidup pada kisaran suhu optimal $23-34^{\circ} \mathrm{C}$ (Lam, 1974). Menurut Floeter et al. (2005), pola distribusi ikan herbivora sangat dipengaruhi oleh suhu perairan, karena ikan herbivora mengalami kendala fisiologis dalam aktivitas makan dan proses pencernaan makanan yang berkaitan dengan suhu. Carr et al. (2018) menemukan tingkat pengembalaan ikan-ikan herbivora meningkat seiring meningkatnya suhu perairan, begitu pula sebaliknya.

Kisaran nilai salinitas $30,15 \pm 0,09$ $31,38 \pm 0,03$ PSU dan pH 7,31 $\pm 0,01$ $7,47 \pm 0,01$ masih optimal bagi kehidupan $S$. canaliculatus. Menurut Lam (1974), $S$. canaliculatus mampu hidup pada perubahan salinitas yang luas dengan kisaran 17-37\%o, bahkan dapat bertahan pada salinitas rendah hingga 5\%, yang ditunjukan oleh fakta ikan ini hidup pada daerah padang lamun dengan salinitas berfluktuasi, dan menurut Lam (1974), S. canaliculatus sangat sensitif terhadap $\mathrm{pH}$ yang tinggi $(>9)$. Kisaran nilai oksigen terlarut yang didapatkan 5,96 $\pm 0,04$ $6,42 \pm 0,05 \mathrm{mg} / \mathrm{L}$ masih optimal mendukung kehidupan ikan baronang yang mampu beradaptasi pada lingkungan perairan yang mengalami penurunan kadar oksigen terlarut, namun menurut Lam (1974) S. canaliculatus sensitif terhadap kadar oksigen terlarut di bawah $2 \mathrm{mg} / \mathrm{L}$.

Rata-rata nilai fosfat $0,0336 \pm 0,0006$ $0,0434 \pm 0,0006 \mathrm{mg} / \mathrm{L}, \quad$ dan nitrat $0,0260 \pm 0,0003-0,0342 \pm 0,0004 \quad \mathrm{mg} / \mathrm{L}$. Tingginya nilai fosfat dan nitrat pada lokasi penelitian dimungkinkan karena aktivitas antropogenik seperti buangan limbah rumah tangga, aktivitas lahan pertanian dan aktivitas perikanan budidaya (keramba jaring apung). Erftemeijer \& Middelburg (1995) menjelaskan bahwa daun dan akar lamun tropis memiliki kemampuan yang seimbang dalam menyerap dan mendaur ulang nutrien (fosfat dan nitrat), selanjutnya mendukung produktivitas lamun. 
Rata-rata nilai klorofil-a $1,31 \pm 0,02$ $2,50 \pm 0,07 \mathrm{mg} / \mathrm{m}^{3}$, nilai tertinggi pada habitat padang lamun vegetasi tunggal dengan kerapatan lamun yang rendah (stasiun 3 dan 4). Widianingsih \& Riniatsih (2009) menyimpulkan bahwa kandungan klorofil-a mikrofitobentos yang tinggi pada habitat lamun dengan kerapatan rendah dan kandungan nutrien yang tinggi, dimana semakin tinggi nilai kerapatan padang lamun, semakin sedikit penetrasi cahaya yang sampai ke kolom perairan sehingga mengakibatkan kecilnya nilai klorofil-a mikrofitobentos.

Grafik Biplot PCA (Figure 2) memperlihatkan karakter parameter lingkungan penciri, stasiun 3 dan 4 membentuk grup tersendiri dengan penciri yang hampir mirip yaitu: turbiditas, oksigen terlarut (DO), klorofil-a dan temperatur. Stasiun 1 membentuk grup tersendiri dengan penciri fosfat, nitrat, dan bersama-sama dengan stasiun 2 memiliki penciri salinitas dan $\mathrm{pH}$, dimungkinkan karena tidak ada pengaruh sungai yang dapat menyebabkan berfluktuasinya $\mathrm{pH}$ dan salinitas, tambahan penciri kedalaman pada stasiun 2 membentuk grup yang terpisah.

Figure 2 memperlihatkan hubungan antar parameter fisika-kimia dan biologi lingkungan, dimana nutrien (fosfat dan nitrat) berkorelasi positif dengan klorofil-a, tingginya kekeruhan seiring tingginya klorofil-a. Temperatur dan nutrien berkorelasi negatif dengan kedalaman, semakin dalam perairan maka temperatur dan nutrien akan semakin rendah. Hal ini diduga berkaitan dengan jarak yang semakin jauh dari garis pantai, begitu pula nilai salinitas dan $\mathrm{pH}$ berbanding terbalik dengan kekeruhan, klorofil-a dan oksigen terlarut, diduga dipengaruhi oleh keberadaan muara sungai pada stasiun 3 dan 4 pembawa material lumpur dan padatan tersuspensi serta nutrien antropogenik yang meningkatkan kekeruhan dan klorofil-a, sekaligus memengaruhi fluktuasi nilai salinitas dan $\mathrm{pH}$. Menurut Livingston et al. (1998) salinitas, suhu, dan kedalaman adalah variabel penting yang mengendalikan pertumbuhan lamun, sedangkan karakteristik sedimen dan nutrien sangat menentukan distribusi spasial vegetasi lamun di wilayah pesisir.

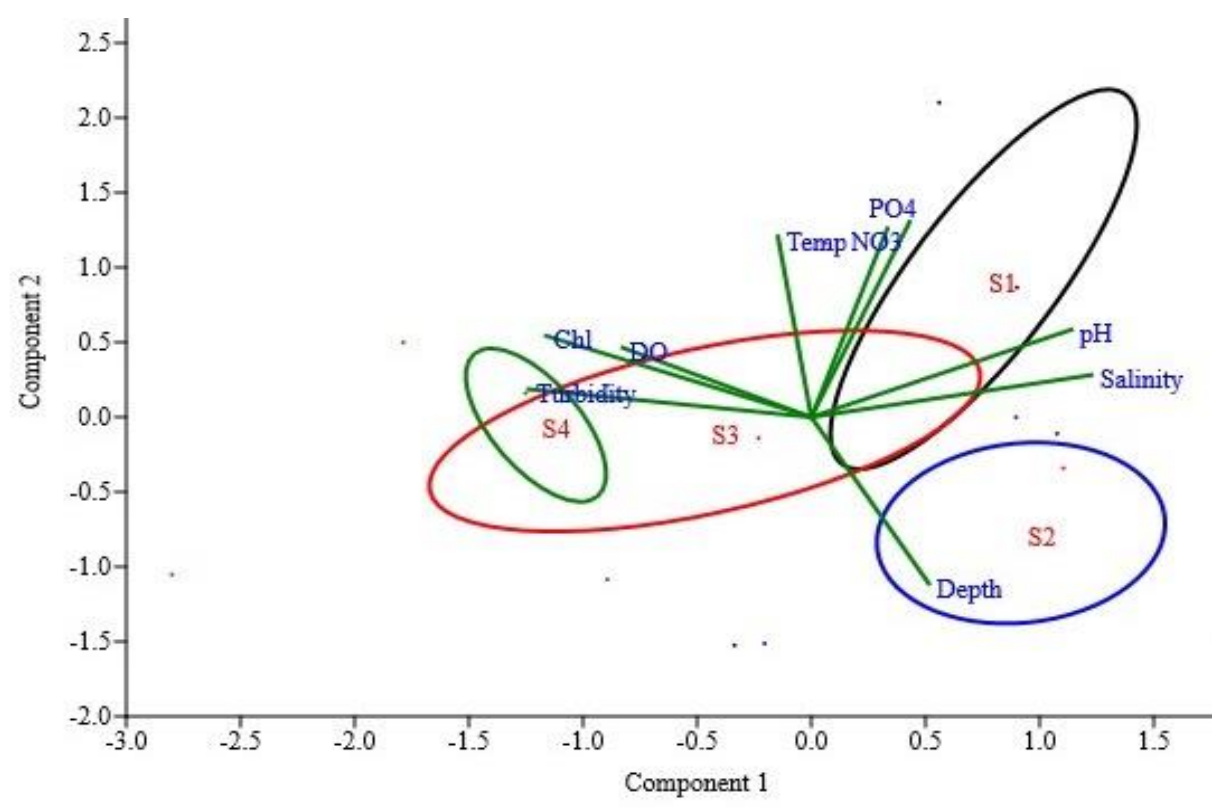

Figure 2. Graph of the PCA Biplot that identifies the research station and the relationship between environmental parameters. Caption: $S 1=$ Station 1, S2 = Station 2, S3 = Station 3, S4 = Station 4. 
Figure 2 juga dapat menyimpulkan bahwa padang lamun yang berdekatan dengan daerah aliran sungai (stasiun 3 dan 4) sangat rentan terhadap kekeruhan yang tinggi, begitu pula pada habitat lamun yang berdekatan dengan pemukiman penduduk (stasiun 1) yang rentan terhadap kesuburan berlebihan akibat masukan nutrien antropogenik secara langsung. Quiros et al. (2017) menyimpulkan bahwa pola penggunaan lahan di daratan memengaruhi integritas ekologis lamun dekat daerah aliran sungai, dimana aktivitas lahan pertanian serta aktivitas antropogenik lainnya berdampak negatif terhadap kondisi lamun.

\subsection{Kondisi dan Kerapatan Jenis Lamun}

Hasil estimasi kerapatan dan keragaman jenis lamun pada empat stasiun pengamatan di perairan TAD (Figure 3).

Figure 3 memperlihatkan habitat lamun dengan vegetasi campuran di $\mathrm{Tg}$. Tiram dan Halong diperoleh 5 jenis lamun (Enhalus acoroides, Thalassia hemprichii, dan Halophila ovalis, Cymodocea rotundata dan Halodule pinifolia). Adapun habitat lamun dengan vegetasi tunggal di Poka dan Nania pada keduanya hanya ditemukan jenis E. acoroides. Tipe substrat di Tg. Tiram adalah dominan pasir halus, Halong dengan pasir kasar, sedangkan stasiun Poka dan Nania didominasi substrat lumpur berpasir.

Figure 3 memperlihatkan keempat stasiun pengamatan dengan komposisi dan kerapatan jenis lamun yang berbeda dengan tipe vegetasi campuran dan tunggal. Terlihat bahwa $E$. acoroides ditemukan dengan kerapatan berkisar 10,64-15,28 tegakan $/ \mathrm{m}^{2}$. Pada Poka dan Nania, kerapatan E. acoroides rendah dikarenakan sebarannya terpencarpencar (patches) membentuk rumpun dengan jumlah relatif sedikit, namun karena memiliki daun yang relatif lebih panjang dibandingkan jenis yang sama pada stasiun 1 dan 2, sehingga terlihat rimbun membentuk padang yang luas. Erftemeijer et al. (1993) menemukan jenis lamun $E$. acoroides memiliki pertumbuhan yang lebih baik pada substrat berlumpur. Pada habitat lamun campuran, jenis $C$. rotundata memiliki kerapatan 2-3 kali lipat jenis lainnya di stasiun 2 (Halong). Hal ini dikarenakan lamun jenis ini memiliki ukuran yang lebih kecil dan penyebarannya terbatas dari arah garis pantai ke zona pertengahan mengarah ke laut. Pada lokasi ini juga $H$. pinifolia dan $H$. ovalis memperlihatkan kerapatan lebih tinggi dibandingkan dengan stasiun 1 ( $\mathrm{Tg}$. Tiram). Nilai kerapatan sebaliknya

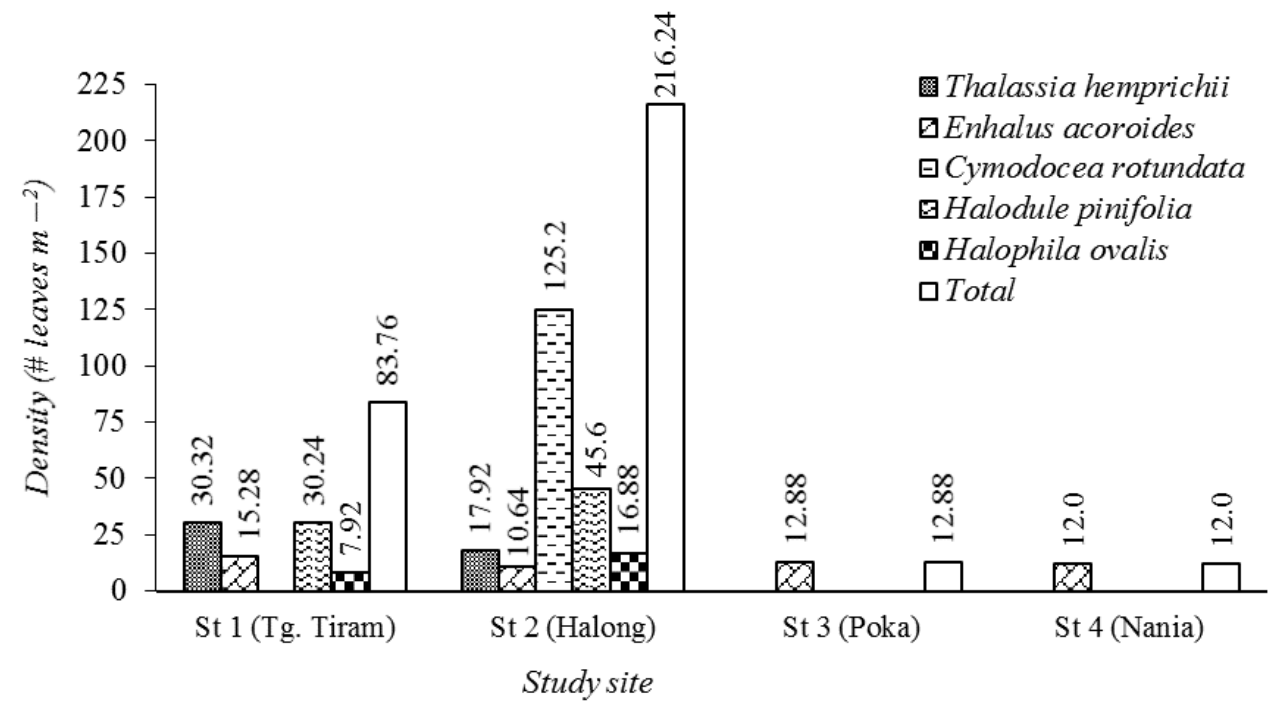

Figure 3. Histogram of the density and diversity of seagrass species in each research station in the Inner Ambon Bay. 
ditemukan pada jenis T. hemprichii. Menurut Kuriandewa et al. (2003), bahwa substrat dasar habitat yang ditumbuhi E. acoroides dan T. hemprichii adalah lumpur sampai pasir, sementara $H$. pinifolia dan $H$. ovalis merupakan jenis pioner yang ditemukan tumbuh pada substrat pasir.

Teluk Ambon Dalam tergolong unik karena ditemukan tipe habitat lamun yang berbeda. Berdasarkan keragaman vegetasinya, lamun di lokasi studi menurut Brouns \& Heijs (1991) merupakan ciri khas kawasan tropis, yakni terdapat 3 asosiasi spesies, yaitu: (1) padang lamun vegetasi tunggal terdiri dari satu spesies tunggal, (2) padang lamun asosiasi 2 atau 3 spesies, dan (3) padang lamun vegetasi campuran sedikitnya 4 dari 7 spesies yaitu: $C$. rotundata, $C$. serrulata, E. acoroides, Halodule uninervis, $H$. ovalis, Syringodium isoetifolium dan $T$. hemprichii dan selalu terdapat jenis $E$. acoroides dan T. hemprichii.

\subsection{Distribusi Spasial Ikan Baronang}

Jumlah ikan baronang ( $S$. canaliculatus) yang terkumpul selama penelitian adalah 1.050 ekor yang terdiri dari 598 ekor jantan dan 452 ekor betina.
Berdasarkan urutan total jumlah individu dan jenis kelamin pada setiap stasiun, Tg. Tiram (290; 202, 88), Halong $(53 ; 34,19)$ (Figure 4), Poka (308; 162, 146), dan Nania (399; 200, 199) (Figure 5).

Kelimpahan $S$. canaliculatus tertinggi pada semua stasiun pengamatan adalah fase juvenil (kelompok ukuran 32,5 mm, selang kelas 25,0-39,9 mm) (Figure 4). Suardi et al. (2016) mendapatkan komposisi tertinggi ukuran juvenil (34-45 mm) pada habitat padang lamun dibandingkan estuari dan terumbu karang. Fenomena ini menunjukkan fungsi padang lamun sebagai daerah pembesaran. Menurut McDevitt-Irwin et al. (2016) padang lamun dijadikan sebagai habitat pembesaran yang mendukung kepadatan, pertumbuhan atau kelangsungan hidup ikan juvenil dibandingkan habitat lainnya, sehingga mendukung distribusi spasial ikan antar habitat (habitat ontogenetik) pada perairan pesisir (Campbell et al., 2011; Honda et al., 2013; Whitfield, 2017; Lee et al., 2019).

Stasiun 1 didominasi kelompok pradewasa (ukuran nilai tengah kelas 77,5 dan 92,5 mm), sedangkan stasiun 3 dan 4 didominasi ukuran dewasa $(137,5 ; 152,5$;

\section{Mixed Seagrass Habitat}

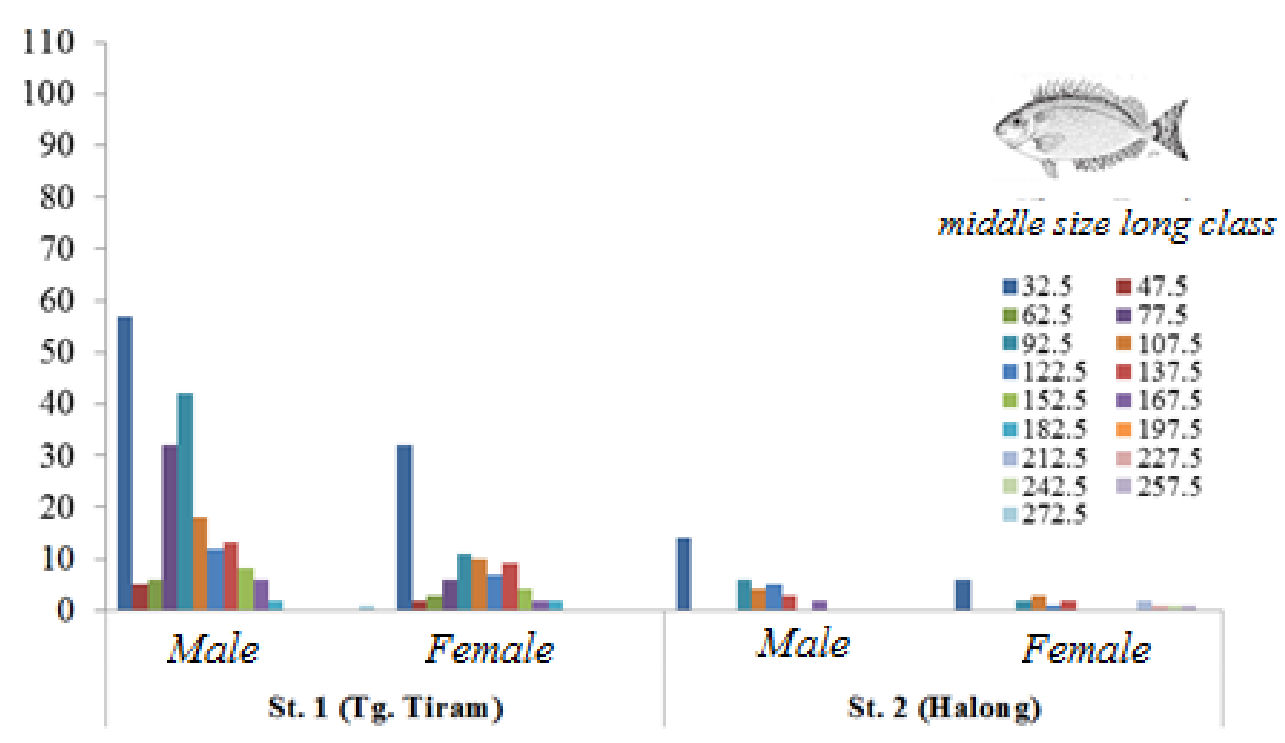

Figure 4. Histogram of length distribution of S. canaliculatus on mixed seagrass beds. 
Monospecific Seagrass Habitat

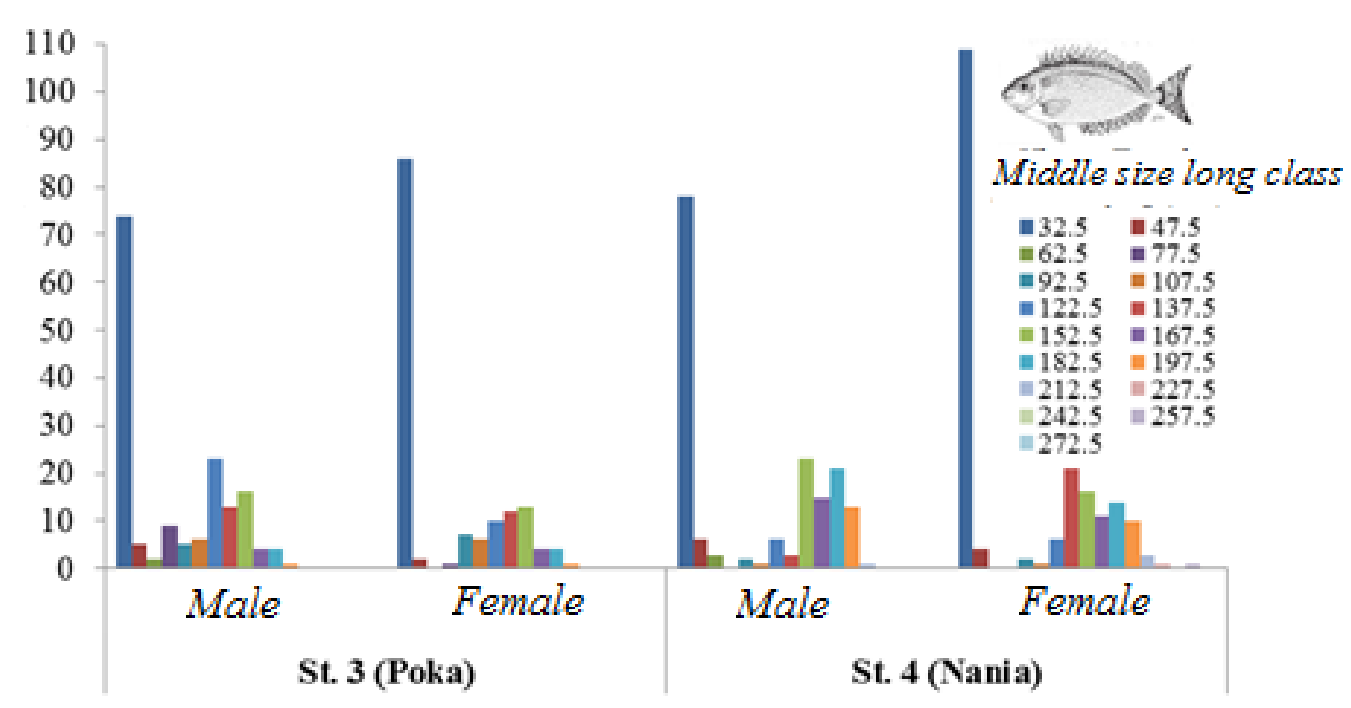

Figure 5. Histogram of length distribution of S. canaliculatus on monospecific seagrass beds.

$167,5 ; 182,5 ; 197,5 \mathrm{~mm})$. Fenomena ini menunjukkan perbedaan dominasi kelompok ukuran $S$. canaliculatus berdasarkan tipe habitat padang lamun. Berbeda dengan Munira et al. (2010) yang menemukan dominasi tertinggi ukuran nilai tengah kelas 92,5 mm pada setiap stasiun pengamatan dan selanjutnya didominasi ukuran 52,5-112,5 $\mathrm{mm}$ yang cenderung seragam antar habitat padang lamun vegetasi campuran. Tingginya kelimpahan ikan baronang fase juvenil dimungkinkan karena selalu membentuk agregasi dalam jumlah besar jika dibandingkan dengan ukuran dewasa. Sebagaimana menurut Woodland (2001), S. canaliculatus berukuran juvenil umumnya membentuk agregasi dengan jumlah individu yang sangat besar di Teluk dangkal dan dataran terumbu karang. Agregasi berkurang saat dewasa dengan membentuk kelompok yang terdiri dari 20 individu.

$$
\text { Rendahnya kelimpahan }
$$

$S$. canaliculatus pada stasiun 2 (Halong) diduga karena tidak didukung dengan keberadaan hutan mangrove sebagai salah satu habitatnya, jika dibandingkan dengan tiga stasiun lainnya yang disekitarnya ditemukan habitat mangrove. Latuconsina et al. (2015), Suardi et al. (2016), Latuconsina et al.
(2018) dan Latuconsina et al. (2019) mengkonfirmasikan luasnya sebaran $S$. canaliculatus pada habitat padang lamun, disamping itu juga ditemukan cukup dominan pada habitat mangrove dan terumbu karang yang berdekatan dengan padang lamun. Kedua habitat ini turut mendukung kelimpahan $S$. canaliculatus pada habitat padang lamun yang saling terkoneksi melalui ritme pasang surut.

Variasi ukuran S. canaliculatus pada habitat lamun di perairan TAD membuktikan beragam fungsi ekologi padang lamun yang diduga terkait dengan kebiasaan makannya. Mariani \& Alcoverro (1999) menemukan ikan herbivora lebih menyukai jenis $C$. rotundata dan $S$. isoetifolium) yang rendah karbon dan kurang menyukai $E$. acoroides yang berkadar karbon tinggi. Meskipun demikian, ditemukannya $E$. acoroides pada semua stasiun pengamatan (Figure 3) mendukung fungsi padang lamun sebagai tempat mencari makan, dimana E. acoroides memiliki ruang penempelan epifit yang luas sebagai sumber makanan bagi $S$. canaliculatus. Latuconsina et al. (2013); Kwak et al. (2015) dan Muliati et al. (2017) selain mendapatkan fragmen lamun, juga makroalga, larva gastropoda, bivalvia, 
polichaeta, oda dan krustasea pada lambung S. canaliculatus.

Hasil analisis tingkat kemiripan kelompok ukuran ikan antar stasiun pengamatan dianalisis berdasakan jarak Euclidean. Figure 6 memperlihatkan dendrogram berdasakan kesamaan ukuran panjang $S$. canaliculatus, terbentuknya 3 grup, yaitu; grup I merepresentasikan habitat lamun vegetasi tunggal (stasiun 3 dan 4), grup II dan III habitat lamun vegetasi campuran (stasiun 1 dan 2). Figure 6 menunjukkan bahwa ikan jantan dan betina cenderung terdistribusi pada kelompok ukuran yang sama antar stasiun pengamatan. Sebagaimana terkonfirmasi oleh Munira et al. (2010) yang menemukan S. canaliculatus jantan dan betina berada pada sebaran spasial yang sama.
Hasil analisis komponen utama (PCA) dalam bentuk grafik biplot (Figure 7) memperlihatkan distribusi kelompok ukuran panjang S. canaliculatus yang berbeda-beda antar stasiun pengamatan. Terbentuk 3 grup yang merepresentasikan nilai tengah kelas, yaitu grup I asosiasi ikan dewasa (137,5; 152,$5 ; 167,5 ; 182,5$ dan $197,5 \mathrm{~mm}$ ) pada stasiun 3 dan 4, grup II asosiasi ikan pradewasa $(77,5 ; 92,5$ dan 107,$5 ; 122,5 \mathrm{~mm})$ pada stasiun 1, dan grup III tidak memiliki karakter kuat sebagai penciri ukuran tertentu, dimungkinkan karena rendahnya frekuensi kehadiran $S$. canaliculatus selama penelitian. Hyndes et al. (2003) menyimpulkan bahwa keragaman dan ukuran ikan yang berbeda berdasarkan karakteristik kanopi vegetasi lamun yang berbeda, dimana perbedaan komposisi spesies ikan antara habitat lamun

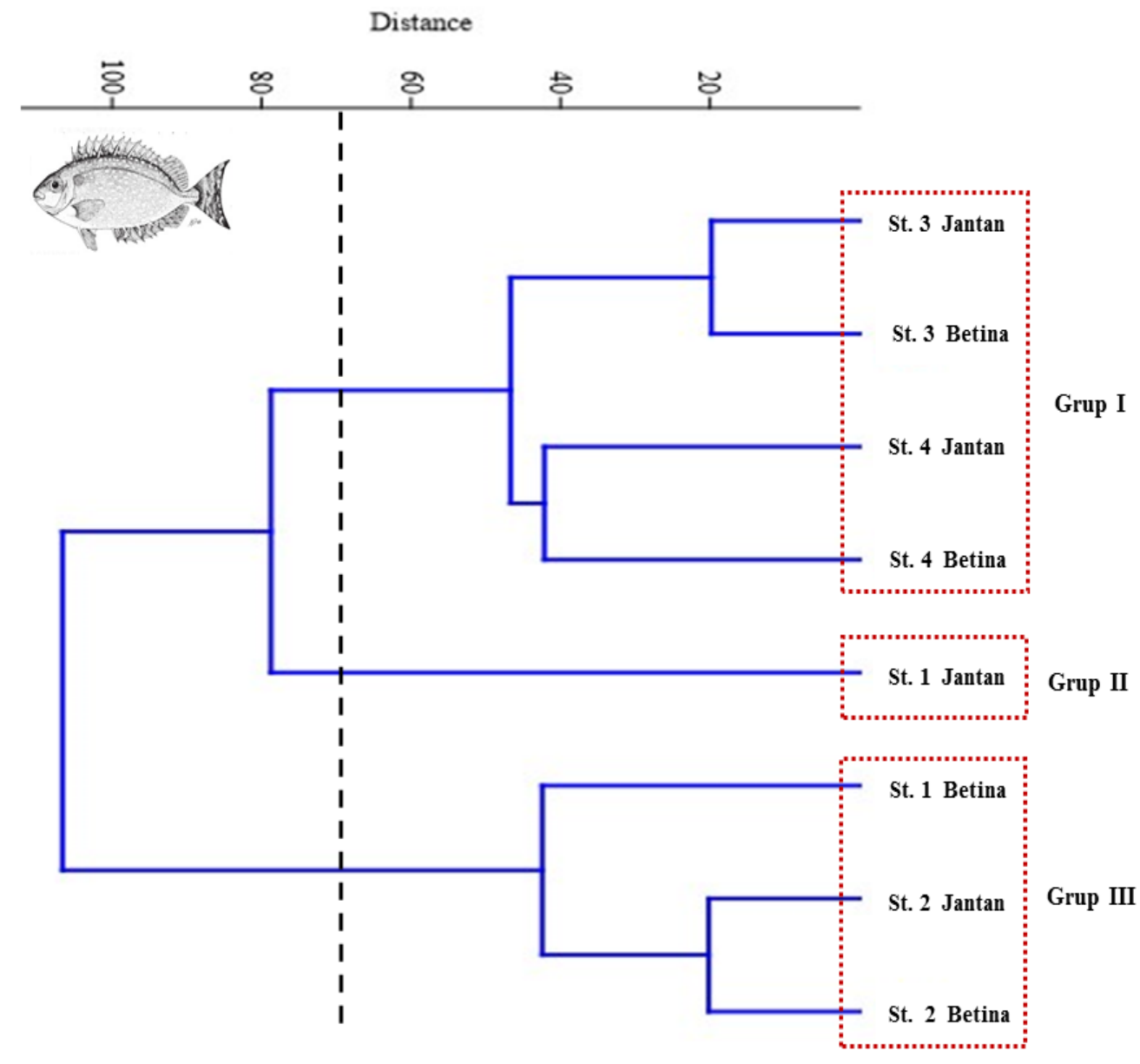

Figure 6. Dendrogram classification of the similarity of $S$. canaliculatus length groups between research stations based on Euclidean distance. 
sebagian mencerminkan komposisi ukuran ikan di habitat masing-masing.

Figure 7 juga menunjukkan hubungan antara distribusi spasial kelompok ukuran panjang $S$. canaliculatus dengan habitat padang lamun. Terdapat korelasi negatif (arah vektor berlawanan) distribusi kelompok ukuran antar habitat padang lamun berbeda. Distribusi ukuran pradewasa berbanding terbalik dengan ukuran dewasa. Distribusi spasial $S$. canaliculatus pada stasiun 3 dan 4 (grup I) dengan habitat lamun vegetasi tunggal dan terletak dekat muara sungai (estuari) cenderung mirip, berbeda dengan stasiun 1 (grup II) dengan habitat lamun vegetasi campuran dan tidak terdapat muara sungai serta dekat dengan terumbu karang. Suardi et al. (2016) menemukan kesamaan ukuran $S$. canaliculatus lebih tinggi antara habitat estuari dan padang lamun jika dibandingkan dengan habitat terumbu karang.

Ukuran juvenil (32,5 dan 47,5 mm) berkorelasi positif (arah vektor membentuk sudut $<90^{\circ}$ antar grup I dan II) yang menunjukkan bahwa ukuran juvenil terdistribusi pada semua tipe habitat padang lamun. Fenomena ini didukung Suardi et al. (2016) yang menemukan S. canaliculatus ukuran juvenil (34-45 mm) terdistribusi luas pada semua habitat (estuari, padang lamun dan terumbu karang). Menurut Lam (1974) dan Kuriandewa et al. (2003), habitat $S$. canaliculatus adalah pada vegetasi lamun

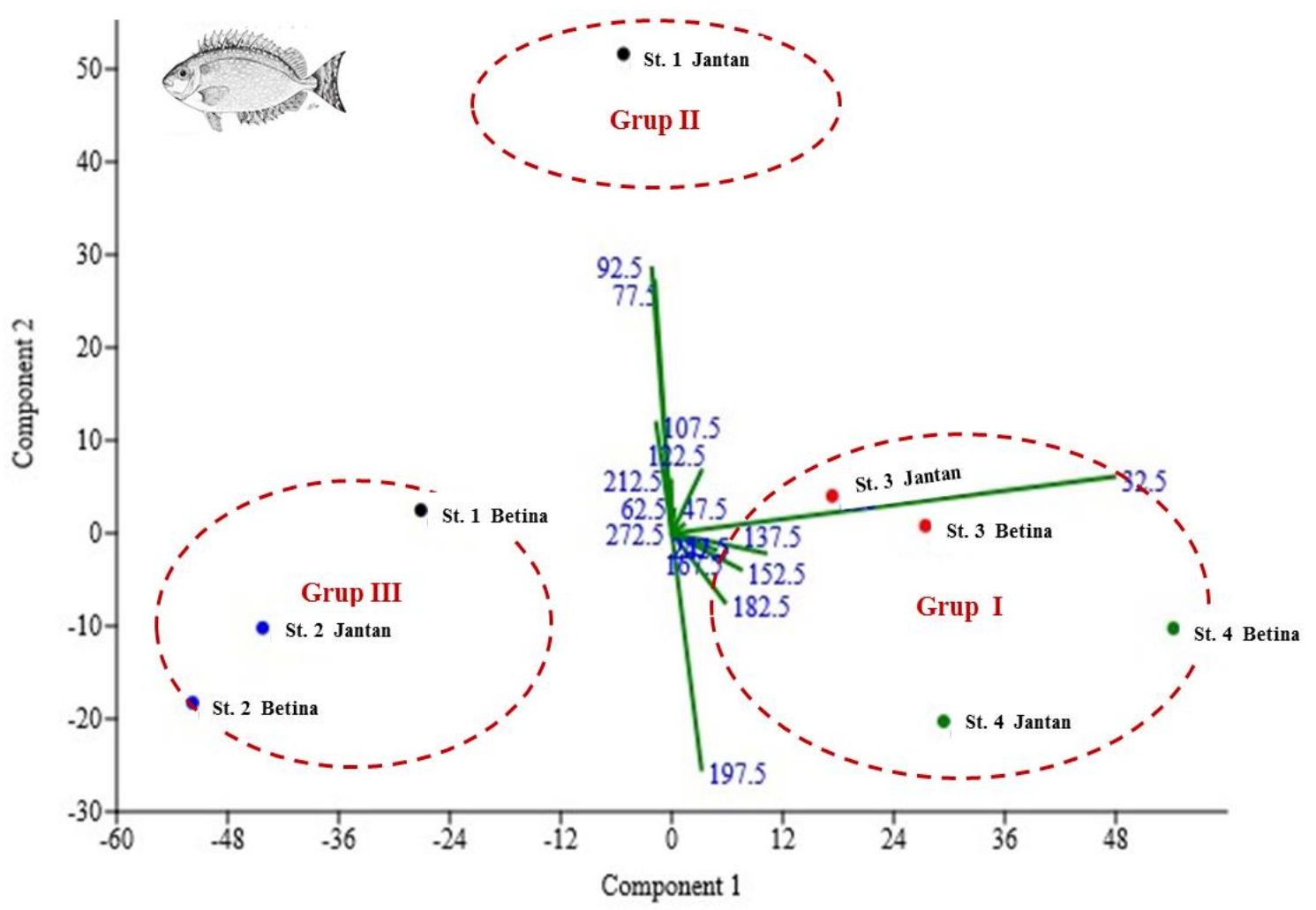

Figure 7. PCA Biplot graph of spatial distribution of S. canaliculatus length groups between research stations. Caption: (Juvenil: Middle Size Class 32.5 (Interval CLass 25.039.9); 47.5: (40.0-54.9); 62.5: (55.0-69.9), Sub Adult (77.5 (70.0-84.9); 92.5 (85.099.9); 107.5 (100.0-114.9); 122.5 (115.0-129.9); Adult (137.5 (130.0-144.9); 152.5 (145.0-159.9); 167.5 (160.0-174.9); 182.5 (175.0-189.9);1897.5 (190.0-204.9); 212.5 (205.0-219.9); 227.5 (220.0-234.9); 242.5 (235.0-249.9); 257.5 (250.0264.9); 272.5 (265.0-279.9). 
umumnya berasosiasi kuat dengan jenis lamun E. acoroides, dan juga pada rataan terumbu karang dan mangrove.

Menurut Larkum et al. (2006), kepadatan awal ikan juvenil pada habitat lamun tergantung pada rekrutmen larva, dan didukung intensitas reproduksi ikan dewasa serta imigrasi pasif dari daerah lain. Ikan juvenil dan dewasa terdistribusi sendiri pada habitat yang disukai, dan gangguan fisik (gelombang) memengaruhi pascarekrutmen dan interaksi biotik yang dipengaruhi karakteristik kanopi lamun.

Hasil penelitian ini menunjukkan bahwa perbedaan struktur ukuran ikan lebih dipengaruhi oleh perbedaan karakteristik vegetasi lamun dibandingkan dengan adanya pengaruh faktor fisik-kimia lingkungan perairan yang cenderung tidak berbeda siginifikan antar stasiun pengamatan, sebagaimana terkonfirmasi temuan AmboRappe (2016) bahwa variabilitas dalam keragaman dan berlimpahnya kumpulan fauna termasuk ikan pada habitat padang lamun dikaitkan dengan kehadiran atau tidak adanya lamun, kepadatan dan atau komposisi spesies lamun, dan bukan karena pegaruh faktor fisik-kimia lingkungan tertentu.

Hasil penelitian ini juga membuktikan peranan habitat padang lamun dalam mendukung distribusi spasial ikan baronang $S$. canaliculatus pada berbagai stadia hidupnya di perairan TAD, sehingga perlu mendapat prioritas dalam upaya pengelolaan (rehabilitasi dan konservasi) agar dapat mempertahankan peranannya dalam mendukung siklus hidup ikan. Menurut McDevitt-Irwin et al. (2016) dan Jianguo et al. (2018), dengan fungsi padang lamun sebagai sumber makanan dan pembesaran ikan juvenil, maka seharusnya menjadi prioritas konservasi untuk mendukung kehidupan sumberdaya hayati ikan dan untuk pemanfaatan perikanan berkelanjutan.

Diperlukan pengendalian aktivitas antropogenik yang berdampak negatif pada habitat padang lamun di sekitar daerah aliran sungai yang dapat meningkatkan kekeruhan dan sedimentasi, sebagaimana rekomendasi Quiros et al. (2017) bahwa pengelolaan padang lamun yang tepat harus bertanggung jawab atas pengelolaan daerah aliran sungai yang berdekatan. Menurut van Katwijk et al. (2011), sistem lamun dapat merespon pengaruh sungai pada tiga tingkatan (tingkat lanskap, ekosistem dan individu), sehingga cocok dijadikan indikator peringatan dini untuk menghindari kerusakan lingkungan yang lebih besar.

Upaya mempertahankan keberadaan habitat padang lamun akan turut mewujudkan perikanan berkelanjutan berbasis lamun, karena dapat mendukung stok perikanan (Unsworth et al., 2010) dan ketahanan pangan (Unsworth et al., 2014). Sebagaimana temuan de la Torre-Castro et al. (2014); Nordlund et al. (2018); Jeyabaskaran et al. (2018); Nordlund et al. (2018); dan Unsworth et al. (2019), yang membuktikan peranan padang lamun sebagai sumber perikanan subsistem, komersial dan rekreasi di wilayah pesisir, sehingga diperlukan pengelolaan untuk mendukung kelangsungan hidup padang lamun sebagai penyedia layanan ekosistem global.

\section{KESIMPULAN}

Ikan baronang $S$. canaliculatus cenderung memiliki preferensi habitat padang lamun yang berbeda berdasarkan stadia hidupnya, pada ukuran juvenil terdistribusi luas di semua tipe habitat padang lamun sehingga membuktikan fungsinya sebagai tempat asuhan dan pembesaran. Ukuran pradewasa cenderung terdistribusi pada tipe habitat padang lamun vegetasi campuran, sedangkan ukuran dewasa pada tipe habitat padang lamun vegetasi tunggal. Tipe habitat padang lamun dan parameter lingkungan memengaruhi distribusi spasial $S$. canaliculatus. Dengan demikian, upaya pengelolaan (rehabilitasi dan konservasi) habitat padang lamun perlu mendapat prioritas termasuk pengelolaan 
daerah aliran sungai beserta pemantauan dan pengendalian aktivitas antropogenik yang dapat mengancam keberadaan habitat padang lamun.

\section{UCAPAN TERIMA KASIH}

Penulis menyampaikan terima kasih kepada Lembaga Pengelola Dana Pendidikan - Kementerian Keuangan Republik Indonesia (LPDP-Kemenkeu RI) atas bantuan Beasiswa Riset Disertasi Tahun Anggaran 2019 No. PRJ-32/LPDP.4/2019.

\section{DAFTAR PUSTAKA}

Ambo-Rappe, R. 2010. Struktur komunitas ikan padang lamun yang berbeda di Pulau Barrang Lompo. J. Ilmu dan Teknologi Kelautan Tropis, 2(2): 6273. https://doi.org/10.29244/jitkt.v2i2.78 53

Ambo-Rappe, R. 2016. Differences in richness and abundance of species assemblages in tropical seagrass beds of different structural complexity. $J$. of Environmental Science and Technology, 9: 246-256. https://doi.org/10.3923/jest.2016.246. 256

Ambo-Rappe, R., M.N. Nessa, H. Latuconsina, \& D.L. Lajus. 2013. Relationship between the tropical seagrass bed characteristics and the structure of the associated fish community. Open J. of Ecology, 3(5): 331-342.

http://doi.org/10.4236/oje.2013.35038

Bengen, D.G. 2000. Teknik pengambilan contoh dan analisis data biofisik sumberdaya pesisir. PSKPL IPB. Bogor. 89 p.

Brouns, J.J.W.M. \& F.A.M.I. Heijs. 1991. Seagrass ecosystem in the tropical West Pacific". In Mathieson and Nienhuis (eds). Intertidal and Litoral Ecosystem. Serie Ecosystem of the
World, No. 24. Elsevier Science Pub. New York. 371-390 pp.

Bulmer, R.H., M. Townsend, T. Drylie, \& A.M. Lohrer. 2018. Elevated turbidity and the nutrient removal capacity of seagrass. Front. Maranie Science, 5(462): 1-9. https://doi.org/10.3389/fmars.2018.00 462

Burhanuddin, A.I. 2019. Biologi kelautan. Lily Publisher. Yogyakarta. 230 p.

Campbell, S.J., T. Kartawijaya, \& E.K. Sabarini. 2011. Connectivity in reef fish assemblages between seagrass and coral reef habitats. Aquatic Biology, 13: 65-77. https://doi.org/10.3354/ab00352

Carr, L.A., R.K Gittman, \& J.F. Bruno. 2018. Temperature influences herbivory and algal biomass in the Galápagos Islands. Front. Mar. Sci., 5(279): 110.

https://doi.org/10.3389/fmars.2018.00 279

Christianen, M.J.A., J. van Belzen, P.M.J. Herman, M.M. van Katwijk, L.P.M. Lamers, \& P.J.M. van Leent. 2013. Low-canopy seagrass beds still provide important coastal protection services. PLoS One, 8(5): 1-8. https://doi.org/10.1371/journal.pone.0 062413

de la Torre-Castro, M., G.D. Carlo, \& N.S. Jiddawi. 2014. Seagrass importance for a small-scale fishery in the tropics: The need for seascape management. Marine Pollution Bulletin, 83: 398-407. http://doi.org/10.1016/j.marpolbul.20 14.03 .034

Duray, M.D. 1998. Biology and culture of siganids. Aquaculture Department Southeast Asian Fisheries Development Center (SEAFDEC). Tigbauan, Iloilo, Philippines. 62 p.

Effendi, H. 2003. Telaah kualitas air bagi pengelolaan sumberdaya perairan dan 
lingkungan. Kanisius. Yogyakarta. $258 \mathrm{p}$.

Erftemeijer, P.L.A. \& J.J. Middelburg. 1995. Mass balance constraints on nutrient cycling in tropical seagrass beds. Aquatic Botany, 50(1):21-36. https://doi.org/10.1016/03043770(94)00440-W

Erftemeijer, P.L.A. dan G. Allen. 1993. Fish fauna of seagrass beds in south Sulawesi, Indonesia. Rec. West. Aust. Museum, 16(2):269-277.

Erftemeijer, P.L.A., R. Osinga, \& A.E. Mars. 1993. Primary production of seagrass beds in South Sulawesi (Indonesia): a comparison of habitats, methods and species. Aquatic Botany, 46(1): 6790.

https://doi.org/10.1016/0304-

3770(93)90065-5

Floeter, S.R., M.D. Behrens, C.E.L. Ferreira, M.J. Paddack, \& M.H. Horn. 2005. Geographical gradients of marine herbivorous fishes: patterns and processes. Marine Biology, 146: 1435-1447.

https://doi.org/10.1007/s00227-0050027-0

Honda, K., Y. Nakamura, M. Nakaoka, W.H. Uy, \& M.D. Frotes. 2013. Habitat use by fishes in coral reefs, seagrass beds and mangrove habitats in the Philippines. PLOS ONE, 8(8): 1-10. https://doi.org/10.1371/journal.pone.0 065735

Hyndes, G.A., A.J. Kendrick, L.D. MacArthur, \& E. Stewart. 2003. Differences in the species and size composition of fish assemblages in three distinct seagrass habitats with differing plant and meadow structure. Marine Biology, 142: 1195-1206. https://doi.org/10.1007/s00227-0031010-2

Irawan, A. \& M.N. Nganro. 2016. Sebaran lamun di Teluk Ambon Dalam. J. Ilmu dan Teknologi Kelautan Tropis, 8(1): 99-114. https://doi.org/10.29244/jitkt.v8i1.12 499

Jeyabaskaran, R., J. Jayasankar, T.V. Ambrose, K.C.V. Valsalan, N.D. Divya, N. Raji, P. Vysakhan, S. John, D. Prema, P. Kaladharan, \& V. Kripa. 2018. Conservation of seagrass beds with special reference to associated species and fishery resources. J. of the Marine Biological Association of India, 60(1): 62-70.

https://doi.org/10.6024/jmbai.2018.60 .1.2038-10

Jianguo, D., W. Yanguo, T. Peristiwady, L. Jianji, P.C. Makatipu, H. Ricardo, J. Peilong, L.K. Hoe, \& C. Bin. 2018. Temporal and spatial variation of fish community and their nursery in a tropical seagrass meadow. Acta Oceanologica Sinica, 37(12): 63-72. https://doi.org/10.1007/s13131-0181288-z

Jones, C.M. 2014. Can we predict the future: juvenile finfish and their seagrass nurseries in the Chesapeake Bay. ICES J. of Marine Science, 71(3): 681-688. https://doi.org/10.1093/icesjms/fst142

Junhui, L., H. Yaqin, A.U. Yanu, L. Heshan, M.H. Azkab, W. Jianjun, H. Xuebao, M. Jianfeng, L. Kun, \& Z. Shuyi. 2018. An ecological survey of the abundance and diversity of benthic macrofauna in Indonesian multispecific seagrass beds. Acta Oceanologica Sinica, 37(6): 82-89. https://doi.org/10.1007/s13131-0181181-9

Kuriandewa, T.E., W. Kiswara, M. Utomo, \& S. Soemodihardjo. 2003. The Seagrass of Indonesia. pp.173-178. In Green E.P and Short F.T (eds). 2003 World Atlas of Seagrasses. Prepared by the UIMEP World Conservation Monitoring Centre. University of California Press. Berkeley, USA. 298 p. 
Kwak, S.N., D.W. Klumpp, \& J.M. Park. 2015. Feeding relationships among juveniles of abundant fish species inhabiting tropical seagrass beds in Cockle Bay, North Queensland, Australia. New Zealand J. of Marine and Freshwater Research, 49(2): 205-223.

https://doi.org/10.1080/00288330.201 4.990467

Lam, T.J. 1974. Siganids: their biology and mariculture potential. Aquaculture, 3(4): 325-354.

https://doi.org/10.1016/00448486(74)90001-5

Larkum, A.W.D., R.J. Orth, \& C.M. Duarte. 2006. Seagrasses: biology, ecology and conservation. Springer. Netherlands. 690 p.

Latuconsina, H., M.N. Nessa, \& R. AmboRappe. 2012. Komposisi spesies dan struktur komunitas ikan padang lamun perairan Tanjung Tiram-Teluk Ambon Dalam. J. Ilmu dan Teknologi Kelautan Tropis, 4(1): 35-46. https://doi.org/10.29244/jitkt.v4i1.78 04

Latuconsina, H., R. Ambo-Rappe, \& M.N. Nessa. 2013. Asosiasi ikan beronang (Siganus canaliculatus Park, 1797) pada ekosistem padang lamun perairan Teluk Ambon Dalam. In: Simanjuntak CPH (eds). Prosiding Seminar Nasional Ikan VII Masyarakat Iktiologi Indonesia (MII) 2012, Makassar Golden Hotel, Makassar 12 Juni 2012. 123-137 pp.

Latuconsina, H. \& R. Ambo-Rappe. 2013. Variabilitas harian komunitas ikan padang lamun perairan Tanjung Tiram-Teluk Ambon Dalam. $J$. Iktiologi Indonesia, 13(1): 35-53. https://doi.org/10.32491/jii.v13i1.110

Latuconsina, H., M.H. Sangadji, \& Naudin. 2015. Variabilitas harian ikan padang lamun terkait keberadaan mangrove dan terumbu karang di perairan Pulau Buntal-Teluk Kotania, Kabupaten
Seram Bagian Barat. Dalam Atmadipoera et al (eds.). Prosiding Pertemuan Ilmiah Tahunan-XI ISOI. Swiss Belhotel, Balikpapan, 17-18 November 2014. 81-196 pp.

Latuconsina, H., T. Tuasikal, \& I. Wali. 2018. Struktur komunitas ikan mangrove Pulau Tatumbu Teluk Kotania, Seram Bagian BaratMaluku. In: Hadiaty R.K (eds). Prosiding Seminar Nasional Ikan ke $X$ Masyarakat Iktiologi Indonesia (MII) 2018. Cibinong, Bogor 8-9 Mei 2018. Jilid 1. $345-358$ pp.

Latuconsina, H., A. Padang, \& A.M. Ena. 2019. Iktiofauna di Padang Lamun Pulau Tatumbu Teluk Kotania, Seram Barat - Maluku. J. Agribisnis Perikanan, 12(1): 93-104. https://doi.org/10.29239/j.agrikan.12. 1.93-104

Lee, C.L., C.K.C. Wen, Y.H. Huang, C.Y. Chung, \& H.J. Lin. 2019. Ontogenetic habitat usage of juvenile carnivorous fish among seagrasscoral mosaic habitats. Diversity, 11(25): 1-17. https://doi.org/10.3390/d11020025

Livingston, R.J., S.E. McGlynn, \& N. Niu. 1998. Factors controlling seagrass growth in a gulf coastal system: Water and sediment quality and light. Aquatic Botany, 60: 135-159. https://doi.org/10.1016/S03043770(97)00079-X

Mariani, S. \& T. Alcoverro. 1999. A Multiple-choice feeding-preference experiment utilising seagrasses with a natural population of herbivorous fishes. Marine Ecology Progress Series, 189: 295-299. https://doi.org/10.3354/meps189295

McDevitt-Irwin, J.M., J.C. Iacarella, \& J.K. Baum. 2016. Reassessing the nursery role of seagrass habitats from temperate to tropical regions: a metaanalysis. Marine Ecology Progress Series, 557: 133-143. 
https://doi.org/10.3354/meps11848

McCloskey, R.M \& R.K.F. Unsworth. 2015.

Decreasing seagrass density

negatively influences associated

fauna. Peer J., 23(3): 1-16.

https://doi.org/10.7717/peerj.1053

Muliati, F. Yasidi, \& H. Arami. 2017. Studi kebiasaan makanan Ikan Baronang (Siganus canaliculatus) di perairan Tondonggeu Kecamatan Abeli Sulawesi Tenggara. J. Manajemen Sumber Daya Perairan, 2(4): 287294.

Munira, Sulistiono, \& Zairion. 2010. Distribusi spasial ikan beronang (Siganus canaliculatus) di padang lamun Selat Lonthoir, Kepulauan Banda, Maluku. J. Iktiologi Indonesia, 10(1): 25-33. https://doi.org/10.32491/jii.v10i1.175

Nakamura, Y., K. Hirota, T. Shibuno, \& Y. Watanabe. 2012. Variability in nursery function of tropical seagrass beds during fish ontogeny: timing of ontogenetic habitat shift. Mar. Biol., 159: 1305-1315.

https://doi.org/10.1007/s00227-0121911-z

Nordlund, L.M., R.FK, Unsworth, M. Gullström, \& L.C Cullen-Unsworth. 2017. Global significance of seagrass fishery activity. Fish and Fisheries, 19: 399-412. https://doi.org/10.1111/faf.12259

Ondara, K., U.J. Wisha, \& G.A. Rahmawan. 2017. Karakteristik hidrodinamika di perairan Teluk Ambon untuk mendukung wisata selam. $J$. Kelautan, 10(1): 67-77. https://doi.org/10.21107/jk.v10i1.217 0

Ondiviela, B., I.J. Losada, J.L. Lara, M. Maza, C. Galván, T.J. Bouma, \& J. van Belzen. 2014. The role of seagrasses in coastal protection in a changing climate. Coastal Engineering, 87: 158-168. http://doi.org/10.1016/j.coastaleng.20 13.11.005

Phinrub, W., B. Montien-Ar., J. Promya, \& A. Suvarnaraksha. 2015. Fish diversity and fish assemblage structure in seagrass meadows at Sikao Bay, Trang Province, Thailand. Open J. of Ecology, 5: 563-573. https://doi.org/10.4236/oje.2015.5120 47

Quiros, T.E.A.L., C. Croll, B. Tershy, M.D. Fortes, \& P. Raimondi. 2017. Land use is a better predictor of tropical seagrass condition than marine protection. Biological Conservation, 209: 454-463.

https://doi.org/10.1016/j.biocon.2017. 03.011

Selano, D.A.J., E.M. Adiwilaga, R. Dahuri, I. Muchsin, \& H. Effendi. 2009. Sebaran spasial luasan area tercemar dan analisis beban pencemar bahan organik pada perairan Teluk Ambon Dalam. J. Torani, 19(2): 96-106.

Setyobudiandi, I., Sulistiono, F. Yulianda, C. Kusmana, S. Hariyadi, A. Damar, Sembiring, \& Bahtiar. 2009. Sampling dan analisis data perikanan dan kelautan; terapan metode pengambilan contoh di wilayah pesisir dan laut. Makaira-FPIK IPB. Bogor. 312 p.

Scott, A.L., P.H. York, C. Duncan, P.I. Macreadie, R.M. Connolly, M.T. Ellis, J.C. Jarvis, K.I. Jinks, H. Marsh, \& M.A. Rasheed. 2018. The role of herbivory in structuring tropical seagrass ecosystem service delivery. Frontiers in Plant Science, 9(127): 1-10. https://doi.org/10.3389/fpls.2018.001 27

Susilo, E.S., N. Sugianto, Munasik, Nirwani, \& C.A. Suryono. 2018. Seagrass parameter affect the fish assemblages in Karimunjawa Archipelago. In Riyadi (eds) Proceedings 3rd International Conference on Tropical 
and Coastal Region Eco Development (ICTCRED 2017), Eastpark Hotel, Yogyakarta, Indonesia. 2-4 October 2017. IOP Conference Series: Earth and Environmental Science, 116(1): 1-7. https://doi.org/10.1088/17551315/116/1/012058

Suardi., B. Wiryawan, A. Taurusman, A.A. Santoso, \& J.M. Riyanto. 2016. Variations in size and catch distribution of white spotted rabbit fish (Siganus canaliculatus) on bioFADs from spatially and temporary point of view, at Luwu District, South Sulawesi, Indonesia. AACL Bioflux, 9(6): 1220-1232.

Syukur, A., Y. Wardiatno, I. Muchsin, \& M.M. Kamal. 2017. Threats to seagrass ecology and indicators of the importance of seagrass ecological services in the coastal waters of East Lombok, Indonesia. American J. of Environmental Sciences, 13(3): 251265.

https://doi.org/10.3844/ajessp.2017.2 51.265

Thangaradjou, T.M. B.K. Prasad, P. Subhashini, S. Raja, E. Dilipan, \& E.P. Nobi. 2015. Biogeochemical processes in tropical seagrass beds and their role in determining the productivity of the meadows. Geochemistry International, 53(5): 473-486.

https://doi.org/10.1134/S0016702915 050055

Unsworth, R.K.F., L.C. Cullen, J.N. Pretty, D.J. Smith, \& J.J. Bell. 2010. Economic and subsistence values of the standing stocks of seagrass fisheries: potential benefits of nofishing marine protected area management. Ocean Coast Manag., 53: 218-224. https://doi.org/10.1016/j.ocecoaman.2 010.04 .002

Unsworth, R.K.F., S.L. Hinder, O.G. Bodger, \& L.C. Culen-Unsworth. 2014. Food supply depends on seagrass meadows in the coral triangle. Environmental Research Letters, 9: 1-9. https://doi.org/10.1088/17489326/9/9/094005

Unsworth, R.F.K., L.M. Nordlund, \& L.C. Cullen-Unsworth. 2019. Seagrass meadows support global fisheries production. Conservation Letters, 12(1): 1-8. https://doi.org/10.1111/conl.12566

van Katwijk, M.M., M.E.W. van der Welle, E.C.H.E.T. Lucassen, J.A. Vonk, M.J.A. Christianen, W. Kiswara, I. Inayat al Hakim, A. Arifin, T.J. Bouma, J.G.M. Roelofs, \& L.P.M. Lamers. 2011. Early warning indicators for river nutrient and sediment loads in tropical seagrass beds: A benchmark from a nearpristine archipelago in Indonesia. Marine Pollution Bulletin, 62: 15121520.

https://doi.org/10.1016/j.marpolbul.2 011.04.007

Waycott, M., K. McMahon, J. Mellors, A. Calladine, \& D. Kleine. 2004. A guide tropical seagrass`of Indo-West Pacific. James Cook University. Townsville. Australia. 72 p.

Whitfield, A.K. 2017. The role of seagrass meadows, mangrove forests, salt marshes and reed beds as nursery areas and food sources for fishes in estuaries. Reviews in Fish Biology and Fisheries, 27: 75-110. https://doi.org/10.1007/s11160-0169454-x

Widianingsih \& I. Riniatsih. 2009. Kandungan Klorofil-a Mikrofitobentos di Padang Lamun Perairan Teluk Awur dan Bandengan, Jepara. J. Ilmu Kelautan, 14(1): 6-13. https://doi.org/10.14710/ik.ijms.14.1. 6-13

Woodland, D.J. 2001. Siganidae, Rabbitfishes (spinefoots) p. 3627 3650. In Carpenter and Niem (eds) 
Distribusi Spasial Ikan Baronang Siganus canaliculatus...

FAO species identification guide for fishery purposes. The living marine resources of the Western Central Pacific. Vol.6. Bony fishes part 4 (Labridae to Latimeriidae). Rome, Received : 24 October 2019

Reviewed : 30 December 2019 FAO. 3381-4218 pp. 